\title{
A validated capillary gas chromatography method for guaco (Mikania glomerata S.) quality control and rastreability: from plant biomass to phytomedicines
}

\author{
Paula C. P. Bueno, Jairo K. Bastos* \\ Departamento de Ciências Farmacêuticas, Faculdade de Ciências Farmacêuticas de Ribeirão Preto, \\ Universidade de São Paulo, Av. do Café s/n, 14040-903 Ribeirão Preto-SP, Brazil
}

\begin{abstract}
RESUMO: "Método validado por cromatografia gasosa capilar para o controle de qualidade e rastreabilidade de guaco (Mikania glomerata S.): da matéria-prima ao fitoterápico". Este trabalho descreve a validação completa de metodologia analítica empregando cromatografia gasosa capilar com padronização interna para quantificação da cumarina (1,2-benzopirona) em produtos contendo guaco (Mikania glomerata Spreng - Asteraceae): xarope, planta e extrato padronizado, além do estudo de estabilidade do fitoterápico em questão. Utilizou-se uma coluna capilar HP-5 (30 $\mathrm{m} \times 0,32 \mathrm{~mm} \times 0,25 \mu \mathrm{m})$, hidrogênio a $1,8 \mathrm{~mL} / \mathrm{min}$ e rampa de temperatura de $100{ }^{\circ} \mathrm{C}$ a $250{ }^{\circ} \mathrm{C}$, a $15{ }^{\circ} \mathrm{C} / \mathrm{min}$. A temperatura do injetor (split $1: 20$ ) foi de $250{ }^{\circ} \mathrm{C}$, enquanto a do detector foi de $270^{\circ} \mathrm{C}$. Os tempos de retenção dos padrões foram: 2,86 minutos para o 1,2 , 3, 4-tetrametilbenzeno, 4,45 minutos para o piperonal (padrões internos) e 5,36 minutos para a cumarina. Após o procedimento de extração da planta in natura, a recuperação da cumarina foi de $101,6 \%$, enquanto que para o xarope esta foi de 100,8 \%. Os limites de detecção e quantificação foram $0,5 \mu \mathrm{g} / \mathrm{mL}$ e $1,5 \mu \mathrm{g} / \mathrm{mL}$, respectivamente. A precisão, determinada para todas as amostras, apresentou desvios padrões relativos menores que $2,5 \%$. Os teores de cumarina presentes nas folhas, extrato e xarope foram de $0,38 \% \mathrm{~m} / \mathrm{m}, 1,33 \mathrm{mg} / \mathrm{mL}$ e $0,143 \mathrm{mg} / \mathrm{mL}$, respectivamente.
\end{abstract}

Unitermos: Mikania glomerata, Asteraceae, cumarina, cromatografia gasosa, validação de métodos, xarope.

\begin{abstract}
This work describes a full validation of a capillary gas chromatography analytical methodology using internal standardization for the quantification of coumarin (1,2-benzopyrone) in guaco (Mikania glomerata Spreng - Asteraceae) products: syrup, plant and its extract, including the stability study of the phytomedicine. For the analysis, it was used an HP-5 capillary column $(30 \mathrm{~m} \times 0.32 \mathrm{~mm} \times 0.25 \mu \mathrm{m})$, hydrogen at a flow rate of $1.8 \mathrm{~mL} / \mathrm{min}$ and the increasing temperature gradient was: $100{ }^{\circ} \mathrm{C}$ to $250{ }^{\circ} \mathrm{C}, 15^{\circ} \mathrm{C} / \mathrm{min}$. The temperature of injector (split 1:20) and detector were kept at $250{ }^{\circ} \mathrm{C}$ and $270{ }^{\circ} \mathrm{C}$, respectively. The retention times of the standards for the above conditions were 2.86 minutes for 1, 2, 3, 4-tetramethylbenzene, $4.45 \mathrm{~min}$ for piperonal (internal standards), and 5.36 minutes for coumarin. After extraction procedure, the recovery of coumarin determined for plant raw material was $101.6 \%$, while for syrup it was $100.8 \%$. Detection and quantification limits were $0.5 \mu \mathrm{g} / \mathrm{mL}$ and $1.5 \mu \mathrm{g} / \mathrm{mL}$, respectively. Precision was determined for all samples and the results were lower than $2.5 \%$. The total amount of coumarin in plant raw material, its extract and syrup were $0.38 \% \mathrm{w} / \mathrm{w}, 1.33$ $\mathrm{mg} / \mathrm{mL}$ and $0.143 \mathrm{mg} / \mathrm{mL}$, respectively.
\end{abstract}

Keywords: Mikania glomerata, Asteraceae, coumarin, gas chromatography, method validation, syrup.

INTRODUCTION

Since earlier times, medicinal plants are used for the treatment of human diseases and nowadays they still make an important key for primary health care. It was observed that, in the last years, it has been an increasing interest by the large companies and some governments in such products, stimulating their standardization and the development of reliable quality control analytical methodologies to support their safety and efficacy (WHO, 1998; Calixto, 2000; Springfield et al., 2005; Ferrante et al., 2007; Migliato et al., 2007; Chaves \& Costa, 2008; Engel et al., 2008).

Traditionally, for medicinal plants, these analytical methodologies include classical physicalchemical assays, like identification, water content, chemical assay of active compounds, total/insoluble ash, etc. (Calixto, 2000; Ong, 2004). Furthermore, for herbal preparations, some tests include quantification 
of the active compounds and uniformity of dosage, disintegration, dissolution among others (Ong, 2004). Concerning the quantification assay and considering the high complexity of this type of matrix, special attention has been given to chromatographic techniques, mainly gas chromatography (GC) and high-performance liquid chromatography (HPLC), due to their advantages such as good separation, efficiency and speed properties (WHO, 1998; Ribani et al., 2004; César et al., 2007; Sousa et al., 2007; Chang et al., 2008).

The specie Mikania glomerata Spreng (Asteraceae), popularly known in Brazil as 'guaco', is widely used as expectorant and to treat respiratory diseases, as well as against fever, syphilis, neuralgia and rheumatism (Corrêa, 1984; Agra et al., 2008; Marliére et al., 2008). Studies reported by Soares de Moura et al. (2001) and Corrêa et al. (2008) supported the indication of M. glomerata products for the treatment of respiratory diseases where broncoconstriction is present, while Fierro et al. (1999) showed the anti-allergenic effects of guaco extract. The described biological effects are mainly due to the presence of coumarin in this plant (Vilegas et al., 1997b; Rocha et al., 2008).

Also, the use of this specie, its therapeutic indication and safety are validated by the Simplified Register list of the Brazilian Health Surveillance Agency (Agência Nacional de Vigilância Sanitária/ANVISA) and Brazilian Pharmacopoeia (Brasil, 2004; Brandão et al., 2006 and 2008; Carvalho et al., 2008).

Despite the extensive use of guaco extracts, it was found that there is a lack concerning the availability of validated methods for the quantitative analysis of coumarin in phytomedicines containg guaco extracts, especially syrups. Furthermore, there is no procedure described for monitoring of the entire manufacturing process, which includes the acquisition of the raw material until the production and standardization of extracts. Nonetheless, the quality control is based on the quantification of the coumarin in the crude plant and in its extracts, through the application of chromatographic techniques, as suggested by Vilegas et al. (1997a), Celeghini et al. (2001), Dos Santos et al. (2006) and Taleb-Contini et al. (2006). Another recent method for the quantification of coumarin in guaco fluid extract and tinctures was performed by first derivative spectrophotometry by Osório and Martins (2004) and Silva et al. (2008).

Therefore, this work reports a single and simply capillary GC method, developed and validated with internal standardization, for the quantification of the coumarin 1,2-benzopyrone in guaco crude plant material, its extract and its commercial syrup, allowing the rastreability of results, including the stability study of the final formulation.

\section{MATERIAL AND METHODS}

\section{Drugs and solvents}

All solvents used for chromatographic purposes were chromatographic grade. Absolute ethanol, ethyl acetate and hexane were supplied by Merck Co (Darmstadt, Germany). The pure synthetic coumarin (1,2-benzopyrone) $99 \%$ was supplied by Fluka Co (St. Louis, MO, USA). Piperonal was supplied by Sigma-Aldrich (St. Louis, MO, USA) and 1, 2, 3, 4-tetramethylbenzene was acquired from Merck Co (Darmstadt, Germany).

\section{Plant material, extract and syrup}

Authentic leaves and branch tips of $M$. glomerata were purchased from Quimer Comércio de Ervas Ltda (São Paulo, SP, Brazil). The dried raw material was grounded to a fine powder using a knife mill, and it was homogenized using a 30 mesh sieve. The standardized guaco extract in aqueous ethanol (1:3) was obtained by maceration and percolation, yielding $5.5 \% \mathrm{w} / \mathrm{v}$ of crude extract. In addition, three batches of guaco syrup containing $10.0 \% \mathrm{v} / \mathrm{w}$ were prepared with this standardized extract.

\section{Sample preparation}

For guaco extract, $10.0 \mathrm{~mL}$ of the sample were transferred to a volumetric flask containing $10.0 \mathrm{mg}$ of piperonal. After complete dissolution, the sample was diluted 10 times in ethanol, from which an aliquot of $1.0 \mu \mathrm{L}$ was injected into the $\mathrm{GC}$ apparatus. Concerning plant material, $0.500 \mathrm{~g}$ of powdered dried leaves and branch tips were transferred to a $50.0 \mathrm{~mL}$ sealed Erlenmeyer flask and macerated with $20.0 \mathrm{~mL}$ of ethanol, containing $200 \mu \mathrm{g} / \mathrm{mL}$ of piperonal, for two hours in a shaker at $120 \mathrm{rpm}$ and at $40{ }^{\circ} \mathrm{C}$. After that, the sample was cooled down to room temperature and filtered through an analytical filter paper. Finally, for syrup, $10.0 \mathrm{~g}$ of the sample and $20.0 \mathrm{~mL}$ of ethyl acetate, containing $100 \mu \mathrm{g} / \mathrm{mL}$ of piperonal, were transferred to a $50.0 \mathrm{~mL}$ Erlenmeyer flask. The flask was hermetically sealed and kept in a magnetic stirrer for 30 minutes at $40{ }^{\circ} \mathrm{C}$. After that, the sample was cooled down to room temperature, and submitted to centrifugation at $20028 \mathrm{x}$ $\mathrm{g}$ for three minutes. An aliquot of the supernatant (2.0 $\mathrm{mL}$ ) was transferred to a vial for further GC analysis.

\section{Chromatographic conditions}

Chromatographic analysis was carried out with a Hewlett-Packard 6890N gas chromatograph (Agilent Technologies, Inc.) equipped with a split/splitless injector inlet and a flame ionization detector. The output was recorded using the workstation which plotted and 
integrated the chromatographic data. An HP-5 capillary column ( $30 \mathrm{~m}$ of length $\mathrm{x} 0.32 \mathrm{~mm}$ of internal diameter $\mathrm{x} 0.25 \mu \mathrm{m}$ of film thickness) was used for the analysis. Hydrogen at a flow rate of $1.8 \mathrm{~mL} / \mathrm{min}$ was employed as the carrier gas and the increasing temperature gradient was: $100{ }^{\circ} \mathrm{C}$ to $250^{\circ} \mathrm{C}, 15^{\circ} \mathrm{C} / \mathrm{min}$. Nitrogen was used as the detector makeup gas at a flow rate of $1.8 \mathrm{~mL} /$ $\min$. The temperatures of the injector (split 1:20) and detector were kept at $250{ }^{\circ} \mathrm{C}$ and $270{ }^{\circ} \mathrm{C}$, respectively.

\section{Method validation}

First of all, the specificity was determined by analyzing the chromatographic profile (retention time and resolution) of the samples (plant, extracts and syrup). Also, a placebo formulation (syrup free of plant extract) and a placebo solution enriched with $0.25 \mathrm{mg} / \mathrm{g}$ of coumarin were compared to an ethyl acetate solution containing only the standard compound (coumarin), in order to verify the interference of matrix constituents.

The linearity responses were determined by injecting ten different concentrations of the standards mixture into the GC apparatus. The solutions of the standards (coumarin, piperonal and 1,2,3,4-tetramethylbenzene) were prepared in ethanol, followed by serial dilution to achieve concentrations ranging from $15.0 \mu \mathrm{g} / \mathrm{mL}$ to $500.0 \mu \mathrm{g} / \mathrm{mL}$. The obtained linear correlations were: 0.9993 for coumarin $(\mathrm{y}=$ $3.0186 \mathrm{x}-36.175), 0.9993$ for piperonal $(\mathrm{y}=1.517 \mathrm{x}$ +13.592 ), and 0.9995 for $1,2,3,4-$ tetramethylbenzene $(y=2.758 x+27.126)$.

The detection and quantification limits were defined as the lowest concentration of the analyte that can be detected and quantified above the noise level of the system, respectively. Both were determined by analyzing the residual standard deviation of the linear regression of three analytical curves.

Precision was determined by preparing and analyzing six samples comprising plant material, extract, syrup and standard solution at a concentration of 200 $\mu \mathrm{g} / \mathrm{mL}$. For that, samples were prepared accordingly to the method described above. The data, obtained under de same experimental conditions, were expressed by the standard deviation of the measures.

For plant material, the accuracy determination was undertaken at the three nominal concentrations $(\mathrm{n}=$ 4), like described in the recovery procedure, performing a standard concentration of $0.50 \%, 1.00 \%$ and $2.00 \%$ of coumarin in the leaves, respectively. The accuracy determination for the syrup was performed in six replicates $(n=6)$ at a concentration of $0.260 \mathrm{mg} / \mathrm{g}$. The accuracy or measure of bias was calculated from the expression:

Bias $(\%)=[($ measured value $)-($ true value $)] \times 100 /($ true value $)$
Additionally, in order to verify and guarantee the response of the method, it was performed an additional accuracy experiment using the coumarin standard in ethanol at the concentrations $0.125,0.250$ and $0.500 \mathrm{mg} / \mathrm{mL}$.

Recovery studies for the plant raw material were carried out in quadruplicate on both coumarin and piperonal, followed by two injections of each sample. For this procedure, $20.0 \mathrm{~g}$ of powdered leaves and branch tips were extracted with ethyl acetate using a soxhlet extractor apparatus until total extraction of coumarin. After that, the plant material, free of coumarin, was carefully dried. Then, three different concentrations of coumarin were incorporated into the plant material $(0.500 \mathrm{~g})$ using $2.5,5.0$ and $10.0 \mathrm{mg}$ of coumarin, respectively plus about $2.0 \mathrm{~mL}$ of ethyl acetate. After complete homogenization, the organic solvent was eliminated, and $20.0 \mathrm{~mL}$ of ethanol containing $200 \mu \mathrm{g} /$ $\mathrm{mL}$ of piperonal were added to all samples, which were processed as described in sample preparation section. The samples were filtered and aliquots of $5 \mathrm{~mL}$ from each one were transferred to flasks containing $2.0 \mathrm{~mL}$ of a $500 \mu \mathrm{g} / \mathrm{mL}$ of another internal standard solution, 1,2,3,4-tetramethylbenzene, which was not submitted to the extraction procedure. It was added just before injection of the sample into the GC apparatus, allowing the quantification of both coumarin and piperonal.

The syrup recovery studies were undertaken in three batches by extracting a sample containing only the standard coumarin at a concentration of 0.26 $\mathrm{mg} / \mathrm{g}$, instead of guaco extract. For that, $10.0 \mathrm{~g}$ of the prepared syrup plus $20.0 \mathrm{~mL}$ of ethyl acetate, containing $100 \mu \mathrm{g} / \mathrm{mL}$ of piperonal, were transferred to a $50.0 \mathrm{~mL}$ Erlenmeyer flask, and submitted to extraction using a magnetic stirrer for $30 \mathrm{~min}$ at $40{ }^{\circ} \mathrm{C}$. The samples were cooled down to room temperature, filtered and analyzed in duplicate.

\section{RESULTS AND DISCUSSION}

Like for all pharmaceutical products, in order to guarantee the quality, efficacy and safety for the human use of M. glomerata, it is mandatory to employ validated analytical methods for the quantification of coumarin as the major chemical marker in both raw material and commercial products.

The developed capillary gas chromatographic method proved to be simple, specific, and reproducible for the quantitative analysis proposed. Following the described chromatographic parameters, coumarin was accurately quantified in guaco syrup, as well as in plant material and its extract.

Performing the specificity test, it was found, for all samples, that there was no compound interfering neither with the peak of coumarin nor with the peaks of the internal standards piperonal and 1, 2, 3, 4-tetramethylbenzene, which were chosen because 
of their solubility, good recovery and excellent linear response. Also, an excellent separation could be

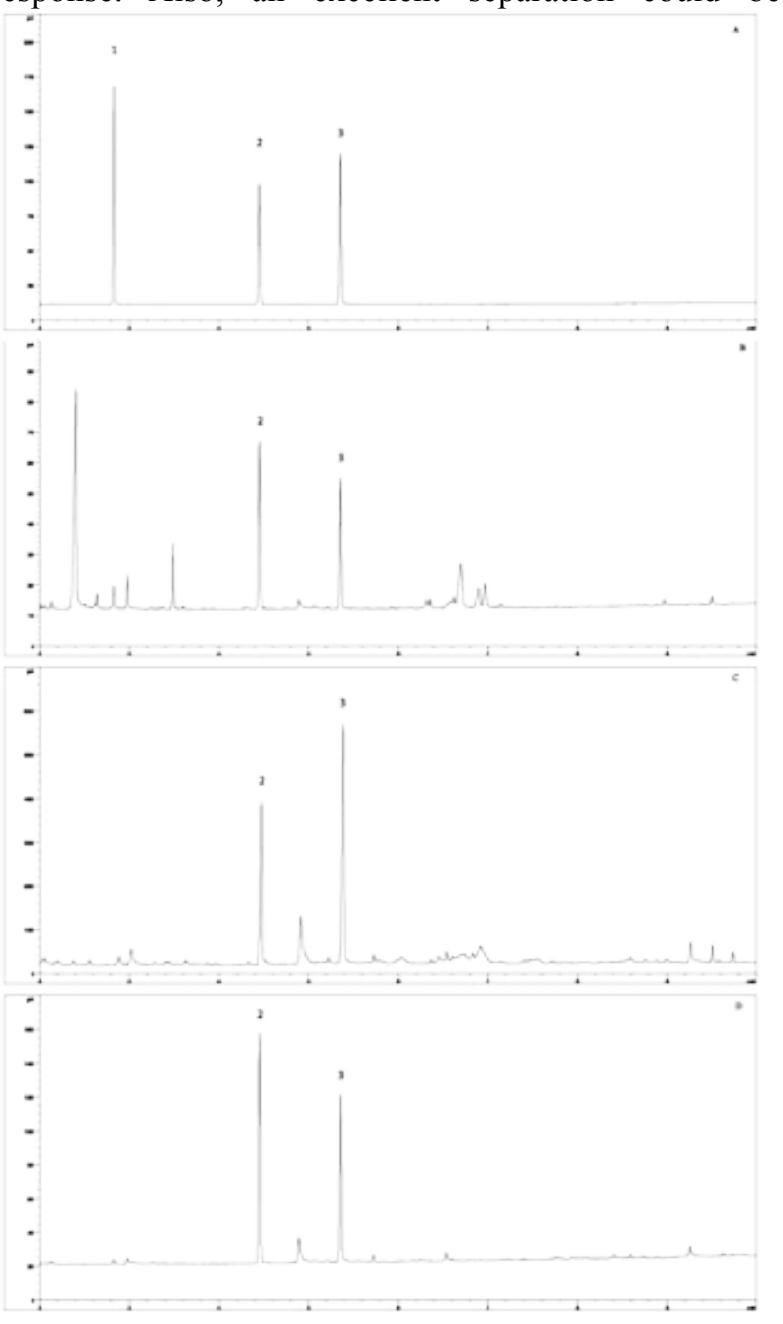

Figure 1. Chromatographic profile of guaco samples: (A) standard mix; (B) syrup; (C) extract; (D) dried leaves; (1) piperonal; (2) 1,2,3,4-tetramethylbenzene; (3) 1,2-benzopyrone (coumarin). For chromatographic conditions please see Material and Methods: Chromatographic conditions.

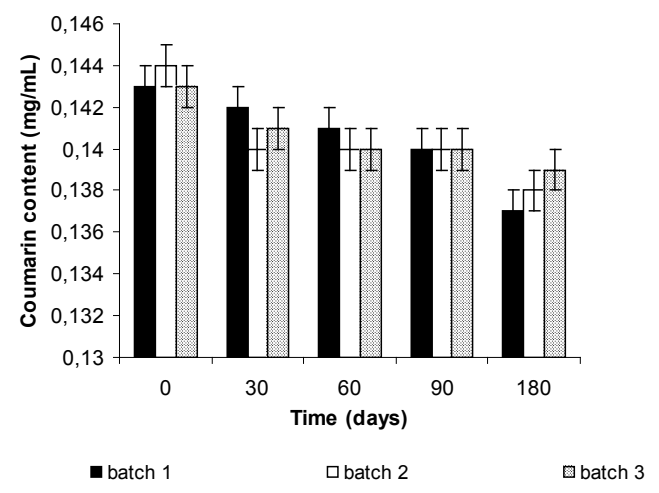

Figure 2. Stability of the three batches of guaco syrup at 0 ,
30, 60, 90 and 180 days under stress conditions: $40{ }^{\circ} \mathrm{C} \pm 2{ }^{\circ} \mathrm{C}$ and $75 \% \mathrm{RH} \pm 5 \%$.

achieved with a good resolution. According to Green (1996) it was acceptable a resolution greater than 1.5, as occurred. Figure 1 also displays the chromatographic profile of all samples analyzed.

As reported in previous work by Bastos et al. (2006), for the dehydrated plant sample, the extraction for one hour at $40^{\circ} \mathrm{C}$ was found to be enough to extract all the coumarin content. However, two hours of extraction were chosen to ensure the extraction of the total amount of coumarin, as determined by the application of several laboratory assays. The sample size was established at $0.500 \mathrm{~g}$ to facilitate the routine analysis of guaco, and to diminish manipulation errors. Ethanol was chosen as extracting solvent not only because of its use in the preparation of the extract by the companies, but also because it worked very well in the developed protocol. Besides, this solvent is safe for both human and environment, cheap and less volatile. Regarding the syrup extraction, ethyl acetate was chosen because of its selective extraction of coumarin, which was carried out for $30 \mathrm{~min}$ at $40^{\circ} \mathrm{C}$, using a magnetic stirrer, allowing the use of low amount of the syrup sample.

In order to certify the system conformity, it was tested the accuracy of an ethanol coumarin standard solution, which was determined to be $101.9 \%$ (data not shown). Later, the recovery of coumarin using the developed procedure was considered to be excellent for dehydrated plant material and syrup.

For plant raw material the accuracy was determined in three concentration levels, with four replicates, for which the highest relative standard deviation (\% RSD) was found to be $1.37 \%$ (Table 1 ), with average accuracy (BIAS) of 2.775, 1.510 and 0.629 , respectively. The obtained recoveries for the coumarin and the internal standard piperonal were 101.6 $\%$ and $95.1 \%$ respectively.

The accuracy determined for the syrup was performed in six replicates at a concentration of 0.260 $\mathrm{mg} / \mathrm{g}$, for which the obtained \% RSD was $1.31 \%$, with average accuracy (BIAS) of 0.897 . The recovery was determined as $100.8 \%$ (data not shown).

The results of the precision experiments are presented in Table 2. It can be inferred that the method is in agreement among individual test results when the procedure is applied repeatedly to multiple samples. The relative standard deviation for all the samples was lower than $2.5 \%$. At least, for the established parameters obtained for coumarin, a LOQ of $1.5 \mu \mathrm{g} / \mathrm{mL}$ and a LOD of $0.5 \mu \mathrm{g} / \mathrm{mL}$ were found.

Concerning the quantitative analysis, it was found $0.38 \% \mathrm{w} / \mathrm{w}$ of coumarin in the plant raw material. In previous work, according to Vilegas et al. (1997a), it was found $0.44 \% \mathrm{w} / \mathrm{w}$ of coumarin in the leaves by GC analysis. These results are quite in agreement, since the coumarin content may vary according to seasonality and 
Table 1. Determination of accuracy for three nominal concentrations $[0.5 \%(5.0 \mathrm{~g} / \mathrm{kg}), 1.0 \%(10.0 \mathrm{~g} / \mathrm{kg})$ and $2.0 \%(20.0 \mathrm{~g} /$ $\mathrm{kg})$ ] of coumarin in the crude plant.

\begin{tabular}{|c|c|c|c|c|c|c|}
\hline \multirow[b]{2}{*}{$\begin{array}{l}\text { True Values } \\
(\mathrm{g} / \mathrm{kg})\end{array}$} & \multirow[b]{2}{*}{$\begin{array}{l}\text { Results of GC } \\
\text { method }(\mathrm{g} / \mathrm{kg})\end{array}$} & \multirow[b]{2}{*}{$\begin{array}{l}\text { Accuracy } \\
\text { (BIAS) }\end{array}$} & \multicolumn{4}{|c|}{ Statistical analysis of the GC results } \\
\hline & & & Mean & S.D. & $\% \mathrm{RSD}$ & $\begin{array}{l}\text { Average } \\
\text { accuracy } \\
\text { (BIAS) }\end{array}$ \\
\hline \multirow{4}{*}{5.0} & 5.088 & 1.760 & \multirow{4}{*}{5.139} & \multirow{4}{*}{0.065} & \multirow{4}{*}{1.26} & \multirow{4}{*}{2.775} \\
\hline & 5.132 & 2.640 & & & & \\
\hline & 5.232 & 4.640 & & & & \\
\hline & 5.103 & 2.060 & & & & \\
\hline \multirow{4}{*}{10.0} & 10.058 & 0.580 & \multirow{4}{*}{10.151} & \multirow{4}{*}{0.139} & \multirow{4}{*}{1.37} & \multirow{4}{*}{1.510} \\
\hline & 10.040 & 0.400 & & & & \\
\hline & 10.344 & 3.440 & & & & \\
\hline & 10.162 & 1.620 & & & & \\
\hline \multirow{4}{*}{20.0} & 20.159 & 0.795 & \multirow{4}{*}{20.126} & \multirow{4}{*}{0.113} & \multirow{4}{*}{0.56} & \multirow{4}{*}{0.629} \\
\hline & 20.079 & 0.395 & & & & \\
\hline & 20.000 & 0.000 & & & & \\
\hline & 20.265 & 1.325 & & & & \\
\hline
\end{tabular}

Table 2. Intra-assay repeatability response for the standard solution, crude plant and syrup.

\begin{tabular}{llll}
\hline \multirow{2}{*}{ Run $\mathrm{n}^{\mathrm{o}}}$. & \multicolumn{2}{l}{ Ratios: areas piperonal/coumarin } \\
\cline { 2 - 4 } & Standard solution & Crude plant & Syrup \\
\hline 1 & 0.779 & 1.514 & 1.419 \\
2 & 0.774 & 1.610 & 1.411 \\
3 & 0.776 & 1.562 & 1.406 \\
4 & 0.771 & 1.579 & 1.421 \\
5 & 0.773 & 1.578 & 1.414 \\
6 & 0.779 & 1.606 & 1.425 \\
Mean & 0.775 & 1.575 & 1.416 \\
Standard Deviation & 0.003 & 0.035 & 0.007 \\
\% RSD & 0.42 & 2.22 & 0.49 \\
\hline
\end{tabular}

site plant harvesting, as well as the storage conditions. For the extract, it was found $1.33 \mathrm{mg} / \mathrm{mL}$ of coumarin. Regarding the syrup, according to ANVISA (Brasil, 2004), the daily recommended coumarin dosage is between $0.525-4.89 \mathrm{mg}$. It was found that, the average of coumarin content in each milliliter of guaco syrup was $0.143 \mathrm{mg}$. Hence, ten milliliters of this syrup provides $1.43 \mathrm{mg}$ of coumarin per dosage, meeting both the efficacy and safety requirements for the use of this formulation. For this reason, another important aim of the developed method was to allow the analysis of the final phytomedicines, especially when the samples were kept under stress conditions, such as high temperatures and humidity. For that, five individual samples of three batches of syrup prepared were submitted to periods of $0,30,60,90$ and 180 days of stress in a climate chamber at $40{ }^{\circ} \mathrm{C} \pm 2{ }^{\circ} \mathrm{C}$ and $75 \% \mathrm{RH} \pm 5 \%$. Afterwards, the samples were analyzed using the developed method (Figure 2). It was observed that there is a slightly decrease in concentration of coumarin along the undertaken stress experiment.

The data presented shows that the developed method is suitable for the routinely quantitative analysis of coumarin in guaco syrup, as well as in plant raw material and in its extract. Besides, it is important to point out that the developed sample preparation allows the reliable quantitative analysis of coumarin compound in a complex matrix containing sugar by gas chromatography, as demonstrated by the described validation procedure.

\section{REFERENCES}

Agra MF, Silva KN, Basílio IJLD, França PF, Barbosa-Filho 
JM 2008. Survey of medicinal plants used in the region Northeast of Brazil. Rev Bras Farmacogn 18: 472-508.

Bastos JK, Freitas LAP, Pagliarussi RS, Merino RE 2006. A rapid quantitative method for the analysis of sulfluramid and its isomers in ant bait by capillary column gas chromatography. J Sep Sci 24: 406-410.

Brandão MGL, Cosenza GP, Moreira RA, Monte-Mor RLM 2006. Medicinal plants and other botanical products from the Brazilian Official Pharmacopoeia. Rev Bras Farmacogn 16: 408-420.

Brandão MGL, Zanetti NNS, Oliveira GRR, Goulart LO, Monte-Mor RLM 2008. Other medicinal plants and botanical products from the first edition of the Brazilian Official Pharmacopoeia. Rev Bras Farmacogn 18: 127-134.

Brasil 2004. Resolução-RE n. 89 de 16 de março de 2004.

Calixto JB 2000. Efficacy, safety, quality control, marketing and regulatory guidelines for herbal medicines (phytotherapeutic agents). Braz J Med Biol Res 33: 179-189.

Carvalho ACB, Balbino EE, Maciel A, Perfeito JPS 2008. Situação do registro de medicamentos fitoterápicos no Brasil. Rev Bras Farmacogn 18: 314-319.

Celeghini RMS, Vilegas JHY, Lanças FM 2001. Extraction and chromatographic analysis of coumarin in hydroalcoholic extracts of Mikania glomerata Spreng. ("guaco") leaves. J Braz Chem Soc 12: 706709.

César IC, Braga FC, Vianna-Soares CD, Nunan EA, Barbosa TAF, Moreira-Campos LM 2007. Determinação de daidzeína, genisteína e gliciteína em cápsulas de isoflavonas por cromatografia em camada delgada (CCD) e cromatografia líquida de alta eficiência (CLAE). Rev Bras Farmacogn 17: 616-625.

Chang R, Piló-Veloso D, Morais SAL, Nascimento EA 2008. Analysis of a Brazilian green propolis from Baccharis dracunculifolia by HPLC-APCI-MS and GC-MS. Rev Bras Farmacogn 18: 549-556.

Chaves JS, Costa FB 2008. A proposal for the quality control of Tanacetum parthenium (feverfew) and its hydroalcoholic extract. Rev Bras Farmacogn 18: 360-366.

Corrêa MP 1984. Dicionário das plantas úteis do Brasil e das exóticas cultivadas. Rio de Janeiro: Imprensa Nacional.

Corrêa MFP, Melo GO, Costa SS 2008. Substâncias de origem vegetal potencialmente úteis na terapia da Asma. Rev Bras Farmacogn 18 (Supl.): 785-797.

Dos Santos SC, Krueger CL, Steil AA, Kreuger MR, Biavatti MW, Wisniewski Junior A 2006. LC Characterisation of guaco medicinal extracts, Mikania laevigata and $M$. glomerata, and their effects on allergic pneumonitis. Planta Med 72: 679-684.

Engel IC, Ferreira RA, Cechinel-Filho V, Meyre-Silva C 2008. Controle de qualidade de drogas vegetais a base de Bauhinia forficata Link (Fabaceae). Rev Bras Farmacogn 18: 258-264.

Ferrante LMS, Mayer B, Vasconcelos EC, Oliveira CMR 2007. GC/FID-based authentication of Baccharis trimera: a quality control study of products commercialized in Curitiba and metropolitan region (Brazil). Rev Bras Farmacogn 17: 356-360.
Fierro IM, Silva ACB, Lopes CS, Moura RS, Barja-Fidalgo CJ 1999. Studies on the anti-allergic activity of Mikania glomerata. Ethnopharmacol 66: 19-24.

Green JMA 1996. A practical guide to analytical method validation. Anal Chem 68: 305-309.

Marliére LDP, Ribeiro AQ, Brandão MGL, Klein CH, Acurcio FA 2008. Utilização de fitoterápicos por idosos: resultados de um inquérito domiciliar em Belo Horizonte (MG), Brasil. Rev Bras Farmacogn 18 (Supl.): 754-760.

Migliato KF, Moreira RRD, Mello JCP, Sacramento LVS, Corrêa MA, Salgado HRN 2007. Controle da qualidade do fruto de Syzygium cumini (L.) Skeels. Rev Bras Farmacogn 17: 94-101.

Ong ES 2004 Extraction methods and chemical standardization of botanicals and herbal preparations. J Chromatogr B 812: 23-33.

Osório AC, Martins JL 2004. Determinação de cumarina em extrato fluido e tintura de guaco por espectrofotometria derivada de primeira ordem. Rev Bras Cienc Farm 40: 481-486.

Ribani M, Botolli CBG, Collins CH, Jardim ICSF, Melo LFC 2004. Validação em métodos cromatográficos e eletroforéticos. Quim Nova 27: 771-780.

Rocha L, Lucio EMA, França HS, Sharapin N 2008. Mikania glomerata Spreng: Desenvolvimento de um produto fitoterápico. Rev Bras Farmacogn 18 (Supl.): 744747.

Silva CR, Gomes VS, Kulkamp IC, Kanis LA 2008. Método espectroscópico para determinação de cumarina em xarope de Mikania glomerata Sprengel. Rev Bras Farmacogn 18: 594-599.

Soares De Moura R, Costa SS, Jansen JM, Silva CA, Lopes CS, Bernardo-Filho M, Nascimento Da Silva V, Criddle DN, Nunes Portela B, Rubenich LMS, Gagliard De Araújo R, Carvalho LCRM 2001. Bronchodilator activity of Mikania glomerata Sprengel on human bronchi and guinea-pig trachea. J Pharm Pharmacol 54: 249-256.

Sousa JPB, Bueno PCP, Gregório LE, Silva Filho AA, Furtado NAJC, Sousa ML, Bastos JK 2007. A reliable quantitative method for the analysis of phenolic compounds in Brazilian própolis by reverse high performance liquid chromatography. J Sep Sci 30: 2656-2665.

Springfield EP, Eagles PKF, Scott G 2005. Quality assessment of South African herbal medicines by means of HPLC fingerprinting. J Ethnopharmacol 101: 75-83.

Taleb-Contini SH, Santos PA, Veneziani RCS, Pereira AMS, França SC, Lopes NP, Oliveira DCR 2006. Differences in secondary metabolites from leaf extracts of Mikania glomerata Sprengel obtained by micropropagation and cuttings. Rev Bras Farmacogn 16 (Supl.): 596-598.

Vilegas JHY, Marchi E, Lanças FM 1997a. Determination of coumarin and kaurenoic acid in Mikania glomerata ("guaco") leaves by high resolution gas chromatography. Phytochem Anal 8: 74-77.

Vilegas JHY, Marchi E, Lanças FM 1997b. Extraction of lowpolarity compounds (with emphasis on coumarin and kaurenoic acid) from Mikania glomerata (guaco) leaves. Phytochem Anal 8: 266-270.

WHO 1998. World Health Organization. Quality control for medicinal plant materials. Geneva: World Health Organization. 